\title{
Modeling of the Dissolution Kinetics of Arbutus Wild Berries-Based Tablets as Evaluated by Electric Conductivity
}

\author{
Permodelan Pembubaran Kinetik Arbutus Beri Liar Berasaskan Tablet Dinilai oleh Kekonduksian Elektrik
}

\author{
TOUNSIA ABBAS-AKSIL \& SALEM BENAMARA*
}

\begin{abstract}
Lyophilized powder (LP) from Algerian arbutus wild berries (Arbutus unedo L.) was obtained. This present paper reports about the dissolution (releasing) properties of LP-based tablets, evaluated through the electric conductivity (EC) of distilled water which is employed as surrounding medium, at three different temperatures (291, 298 and $309 \mathrm{~K})$. In addition to this, secondary physicochemical characteristics such as elementary analysis, color and compressibility were evaluated. Regarding the modeling of ionic transfer, among the three tested models, namely Peleg, Singh et al. and Singh and Kulshestha, the latter seems to be the most appropriate $\left(R^{2}=0.99\right)$, particularly in the case of compacted tablets under $2000 \mathrm{~Pa}$. The temperature dependence of the dissolution process was also studied applying Arrhenius equation $\left(R^{2}>0.8\right)$ which allowed to deduce the activation energy, ranging from 18.7 to $21.4 \mathrm{~kJ}^{\mathrm{mol}} \mathrm{mo}^{-1}$ according to the model and compression force employed.
\end{abstract}

Keywords: Arbutus wild berries (Arbutus unedo L.); dissolution; electric conductivity; powder; tablet

ABSTRAK

Serbuk lyophilized (LP) dari Arbutus beri liar Algeria (Arbutus unedo L.) telah diperoleh. Kertas ini melaporkan tentang sifat pembubaran (pelepasan) tablet berasaskan LP, dinilai melalui kekonduksian elektrik (EC) air suling yang digunakan sebagai medium kelilling, pada 3 suhu yang berbeza (291, 298 dan 309 K). Di samping itu, ciri fizikokimia sekunder seperti analisis asas, warna dan kadar mampatan telah dinilai. Mengenai model pemindahan ionik, antara tiga model yang diuji ialah Peleg, Singh et al. dan Singh dan Kulshestha, dengan yang terakhir paling sesuai $\left(R^{2}=0,99\right)$, terutamanya dalam kes tablet yang dipadatkan di bawah 2000 Pa. Pergantungan suhu dalam proses pembubaran juga dikaji menggunakan persamaan Arrhenius $\left(R^{2}>0.8\right)$ yang dibenarkan untuk menyimpulkan tenaga pengaktifan, antara 18.7 hingga $21.4 \mathrm{~kJ}^{.} \mathrm{mol}^{-1}$ mengikut model dan mampatan daya yang digunakan.

Kata kunci: Arbutus beri liar (Arbutus unedo L.); kekonduksian elektrik; pembubaran; serbuk; tablet

\section{INTRODUCTION}

Arbutus wild berries (Arbutus unedo L.) are Mediterranean typical fruits generally not consumed in fresh form (Ayaz et al. 2000) but after processing (Pawlowska et al. 2006). Like other plants which are endowed with wonderful defense system assured by various biopharmaceuticals (Rahman 2007), the berries are also known to be used in folk medicine as antiseptic, diuretic and laxative (Pallauf et al. 2008). Moreover, this wild fruit is rich in numerous nutriments like calcium and potassium (Ozcan \& Hiciseferogullari 2007), antioxidants (Tawaha et al. 2007) and sugars with a content of about $0.47 \mathrm{~kg} . \mathrm{kg}^{-1}$ dry basis (db) (Alarco E Silva et al. 2001). Among 27 various investigated Algerian fruits, Allane and Benamara (2010) have demonstrated that arbutus berries present the highest reducing power $\left(\sim 20 \mathrm{mg}\right.$ vitamin $\mathrm{C}$ equivalent. $\mathrm{g}^{-1}$ whole fruit), Ruiz-Rodríguez et al. (2011) earlier supported that the higher antioxidant potential of the arbutus berries may be due to the activity of various bioactive components including vitamin $\mathrm{C}$. Based on the fact that any herbal or botanical material containing vitamins and minerals are considered as a dietary ingredients (Devla et al. 2011), arbutus berries may be classified as a dietary supplement.

Despite the importance in the engineering field of powdered food products, the scientific investigation of the latter remains insufficient (Murieta-Pazos et al. 2012). In particular, the powders from arbutus berries (Arbutus unedo L.), to the best of our knowledge, never been studied. But, we have recently evocated in a brief communication the opportunity to produce tablets from arbutus berries powder (Benamara et al. 2012).

This present paper reports essentially about the dissolution (releasing) properties of LP-based tablets, evaluated through the electric conductivity (EC). Fruit tablets are of strong interest for various reasons like extended shelf life and functional properties. Unfortunately, as what was mentioned before, few works are found to be devoted to similar tablets from whole fruits: date (Phoenix dactylifera L.) (Adiba et al. 2011), Terminalia chebula fruit (Prakash et al. 2011), baobab pulp fruit powder as hydrophilic excipient for pharmaceutical tablets (Arama et al. 1989). 


\section{MATERIAL AND METHODS}

\section{FRUIT AND FRUIT POWDER}

Fully ripe Arbutus berries (Figure 1(a)) were randomly picked at various trees in Kabylian region (northern Algeria) in winter 2011. The fruit is submitted to freeze drying at $109 \mathrm{~K}$ (4.5 Pa) during 2 days using lyophilizer of type 'Christ Alpha 1-4LD' provided with vacuum pump (RZ 6, max pressure $=0.04 \mathrm{~Pa})$. The dried product is then ground and sieved (sieve of type EuromatestSintoo, NFX11-501) to obtain homogeneous powder (LP) (Figure 1(b)) which is finally kept in closed glass flask at $277 \mathrm{~K}$.

\section{DISSOLUTION TEST}

First, the LP was characterized by some physicochemical criteria, including $\mathrm{pH}$, water content, ${ }^{\circ} \mathrm{Brix}$, ash, color parameters in CIELab system (Hunter-Lab tristimulus colorimeter Thermocontrol Sarthorieus), flow rate $(\mathrm{g} / \mathrm{s})$ (Patil et al. 2012), Carr's index (CI, \%) (characterizing the compressibility) (Olayemi et al. 2011) and Hausner's ratio (HR) (characterizing the flowness) (Olayemi et al. 2011). Hydraulic laboratory press was employed to obtain tablets from LP by direct compression, applying two pressures (1000 and $2000 \mathrm{~Pa})$. It is generally recognized that among the three tabletting methods applied, namely wet granulation, dry granulation and direct compression, the latter is the most preferred because of its numerous advantages, especially its simplicity (Patel \& Bhavsar 2009).

Subsequently, the dissolution- related properties of tablets at different temperatures 291, 298 and $309 \mathrm{~K}$ were investigated by studying the variation versus time of the electric conductivity (EC) of the dissolution (surrounding) liquids simulating physiologic media (only results related to bidistilled water are presented here) according to the simple system proposed by Jayjock et al. (2005), knowing that the dissolution tests are complex (Yu 2008). In fact, while the common standard dissolution testing like described by United States Pharmacopoeia is generally used to investigate solid delivery systems, some authors have nevertheless adapted a specific methodology. Thus, taking into account the limitation of performing the USP dissolution test in relation to their specific conditions, Young et al. (2008) have assembled a large reservoir upon a magnetic stirrer to simulate the pharmacopoeia dissolution test. The electrical conductivity was measured by means of conductivity meter (Type EC 214 HANNA).

Frenning et al. (2002) have already used the electric conductivity measurement to explore drug dissolution of tablets containing micronized cellulose and $\mathrm{NaCl}$ as a model drug, whereas Brielles et al. (2008) and Chantraine et al. (2006) have employed the electric conductivity to study the phenomenon of dissolution of detergent tablets. On the other hand, Mikac et al. (2007) monitored the dissolution of tablets containing $\mathrm{NaCl}$ and carboxylic acids by following the conductivity changes in surrounding medium by means of electric current density imaging technique, whereas Gauza and Kubisz (2010) performed tablets from collagen in view to study the water release process of this protein, adopting the electric conductivity as quantification criterion of water transfer.

Three mathematical models were used to describe the dissolution of tablets from arbutus-berry powder. The use of three models related to the masse transfer, is dictated principally by the principle of parsimony (Hill 2006). Some types of such models are adapted to study the release process. Weibull model, widely used in food processing, is for example adapted to investigate dissolution/release process (Vudathala \& Rogers 1992) and indicates the accumulated fraction of the drug in solution at any time (Costa \& Sousa Lobo 2001). This is why we attempt to apply analogue models for describing the dissolution process evaluated through the EC of the surrounding media. The dimensionless form of the response seems to us to be particularly interesting to investigate. The three models on which we based our research are detailed as follows.

-Peleg model (Peleg 1988), is widely used to study, before all the rehydration processes, but, Boussetta et al. (2009) have applied this model to investigate the extraction process of polyphenols from grape pomace (Vitis vinifera L.).

The Peleg's model as adapted to the present study can be written as follows:

$$
\sigma=\sigma_{0}+t /\left(k_{1}+k_{2} t\right)
$$

where $\sigma$ and $\sigma_{0}$ are the initial and at any time $(t)$ conductivity $\left(\mathrm{S} . \mathrm{m}^{-1}\right)$, respectively; $t$ is the dissolution duration $(\mathrm{s}) ; k_{l}$ is the Peleg's rate constant (m.s. $\left.\mathrm{S}^{-1}\right)$ and $k_{2}$ is the Peleg's capacity constant $\left(\mathrm{m} \cdot \mathrm{S}^{-1}\right)$.

- Model of Singh and Kulshrestha (Singh \& Kulshrestha 1987):

$$
\left(\sigma_{e}-\sigma\right) /\left(\sigma_{e}-\sigma_{0}\right)=1 /(k t+1)
$$

where $s_{e}$ is the equilibrium conductivity and $k$ is the rate constant $\left(\mathrm{s}^{-1}\right)$.

- Model of Singh et al. (Singh et al. 1981):

$$
\left(\sigma_{\mathrm{e}}-\sigma\right) /\left(\sigma_{\mathrm{e}}-\sigma_{0}\right)=\exp (-\mathrm{kt})
$$

where $k$ is the Singh et al.'s constant $\left(\mathrm{s}^{-1}\right)$.

To elucidate the temperature dependence of the model constants, the following well known Arrhenius equation was used:

$$
k=k_{\mathrm{o}} \exp \left(-E_{a} / R T\right),
$$

where $k_{0}$ is the pre-exponential factor, $E_{a}$ is the activation energy $\left(\mathrm{kJ} . \mathrm{mol}^{-1}\right), \mathrm{R}$ is the constant $\left(8.134 \mathrm{~J} . \mathrm{mol}^{-1} \mathrm{~K}^{-1}\right)$ and 
$\mathrm{T}$ is the absolute temperature $(\mathrm{K})$. By plot the regression right $\ln \mathrm{k}$ versus $1 / \mathrm{T}$ it becomes possible to deduce $\mathrm{Ea}$.

\section{STATISTICAL ANALYSIS}

The statistical analysis of experimental data was performed using Origin software version 7.5.

Goodness of fit of the selected models was evaluated by means of the coefficient of determination $\left(\mathrm{R}^{2}\right)$, sum of square error (SSE) and root mean square error (RMSE).

$$
\begin{aligned}
& \mathrm{SSE}=1 / \mathrm{N} \sum_{\mathrm{i}=1}^{\mathrm{N}}\left(\mathrm{X}_{\mathrm{exp}}-\mathrm{X}_{\text {cal }}\right)^{2} . \\
& \mathrm{RMSE}=\left[1 / \mathrm{N} \sum_{\mathrm{i}=1}^{\mathrm{N}}\left(\mathrm{X}_{\mathrm{cal}}-\mathrm{X}_{\mathrm{exp}}\right)^{2}\right]^{1 / 2},
\end{aligned}
$$

where $\mathrm{X}_{\text {exp }}$ is the experimental value, $\mathrm{X}_{\text {cal }}$ is the value predicted by the model and $\mathrm{N}$ is the number of experimental measurements.

\section{RESULTS AND DISCUSSION}

Round tablets of $(400 \pm 1) \mathrm{mg}$ weight, $12 \mathrm{~mm}$ diameter and $2 \mathrm{~mm}$ thickness were obtained from LP by direct compression, applying two different compression forces (Figure 1(c)). Some physicochemical properties of the LP (Figure 1(b)) are given in Table 1.

Taking into account the importance of the external aspect as quality criterion, the color parameters $\left(\mathrm{L}^{*}, \mathrm{a}^{*}\right.$ and $\left.\mathrm{b}^{*}\right)$ of the LP are similar to those $\left(\mathrm{L}^{*} \sim 30, \mathrm{a}^{*} \sim 10\right.$ and $\mathrm{b}^{*}$ $\sim 25$ ) reported by Orak et al. (2011) for fresh strawberry tree fruits from Turkey, which confirms the efficiency of freeze drying concerning the intrinsic color preservation (Kampuse \& Volkova 2009).

Moreover, the applicability of the direct compression for arbutus berry fruits can be easily observed considering the fact that two following conditions are met (Göczo et al. 2000): Powder flowability with $\mathrm{HR}<1.25$ (see the added Table 1), limit value recognized by Panda et al. (2008); and its compactability/compressibility with $\mathrm{CI}$ value $<15$ (see the added Table 1), as required by the European pharmacopea. Also, Arbutus berry fruit as a rich pectin-material (Ruiz-Rodríguez et al. 2011) can be presumed to be able to undergo direct compression, Salbu (2011) demonstrates that certain pectin present an interesting potential as direct compression excipients in tablets.

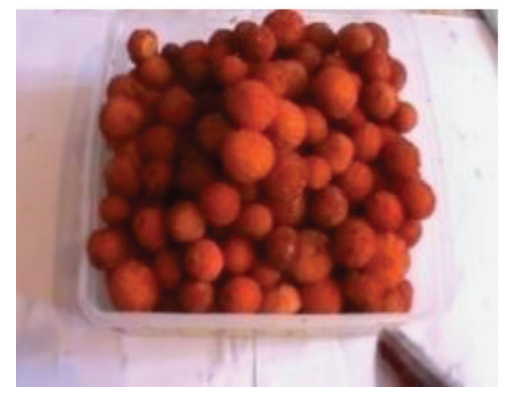

( a)

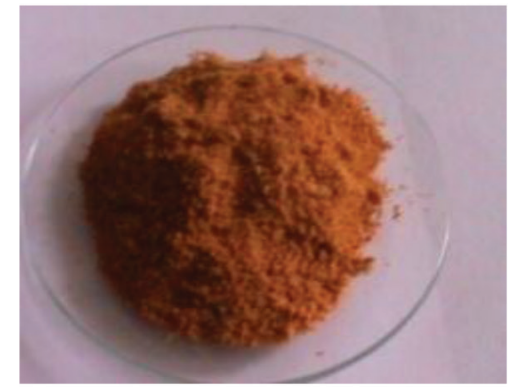

(b)

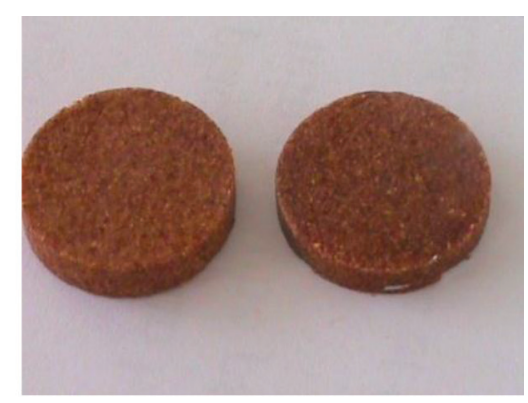

(c)

FIGURE 1. Photographs of the arbutus berry whole fruits (a), their freeze-dried powder (b) and tablets (c) obtained under pressure of 1000 (left) and 2000 Pascal (right)

TABLE 1. Some physical properties of powder from freeze-dried strawberry fruits

\begin{tabular}{lc}
\hline Parameter & Value \\
\hline $\mathrm{pH}$ & $3.83 \pm 0.08$ \\
Water content $(\%)$ & 2.8 \\
${ }^{\circ}$ Brix $(\%)$ & 90.00 \\
Ash $(\%)$ & $3.01 \pm 0.03$ \\
$\mathrm{~L}^{*}$ & 64.48 \\
$\mathrm{a}^{*}$ & 8.51 \\
$\mathrm{~b}^{*}$ & 24.11 \\
$\mathrm{~h}^{\circ}$ & 70.56 \\
$\mathrm{C}^{*}$ & 25.56 \\
$\mathrm{CI}(\%)$ & $13.69 \pm 0.26$ \\
$\mathrm{HR}$ & $1.15 \pm 0.00$ \\
$\theta^{\circ}($ Angle of repose $)$ & 35.00 \\
Flow rate $(\mathrm{g} / \mathrm{s})$ & 10.00 \\
\hline
\end{tabular}

Date are represented as mean $\pm \mathrm{SD}(n=3), \mathrm{HR}=$ Hausner's ratio; $\mathrm{CI}=$ Carr's index $\mathrm{h}^{\circ}=$ Hue angle $=\arctan \left(\mathrm{b}^{*} / \mathrm{a}^{*}\right)$ and $\mathrm{C}^{*}=$ total color $=\left(\mathrm{a}^{* 2}+\mathrm{b}^{* 2}\right)^{0.5}$ 
These tablets can be used as such and/or as carrier for natural active ingredients from plants. As supported by Madrigal-Carballo et al. (2010), the challenge now consists of the incorporation of natural bioactive molecules into dosage forms for preventive and therapeutic applications, knowing that the use of natural materials as drug delivery vehicles arouses interest among scientists, due to numerous advantages like their accessibility (Amin et al.2012). This is why it seemed useful to investigate the behavior of tablets in different surrounding liquids simulating physiologic media, choosing the EC as indicator of release properties of arbutus berry tablets (only data for distilled water are shown here). Obviously, the transport phenomenon concerns electric charge carriers, including organic and non-organic ions. It must be recalled that the tablet dissolution testing is one of the most important test during the developments of solid dosage forms (Ku et al. 2011).

The overall shapes of curves obtained at different temperatures are similar in both applied pressures (Figure 2).
Except for low temperature (291) for which the conductivity variation is negligible, this parameter dramatically increases during dissolution process, the time required to reach the equilibrium state corresponding to the complete disintegration of tablets, being the same (about $1800 \mathrm{~s}$ ) for all experiments. The disintegration time value ranged in the interval (306-3780 s) communicated by Almukainzi et al. (2010) about dietary supplementsbased tablets, knowing also that the USP disintegration standard for vitamin C tablets is of $1800 \mathrm{~s}$ max in water at 310 (Bhagavan \& Wolkoff 1993). In this context, Brielles et al. (2008) has already showed that the kinetic monitoring by EC allows evaluating not only the time of complete dissolution of a tablet but also the nature of the disintegration process: Rapid disintegration, erosion regime and an intermediary regime. Nevertheless, the compression pressure appears to influence considerably the effect of temperature on ion migration. In fact, for compression pressure of $2000 \mathrm{~Pa}$, the equilibrium EC at
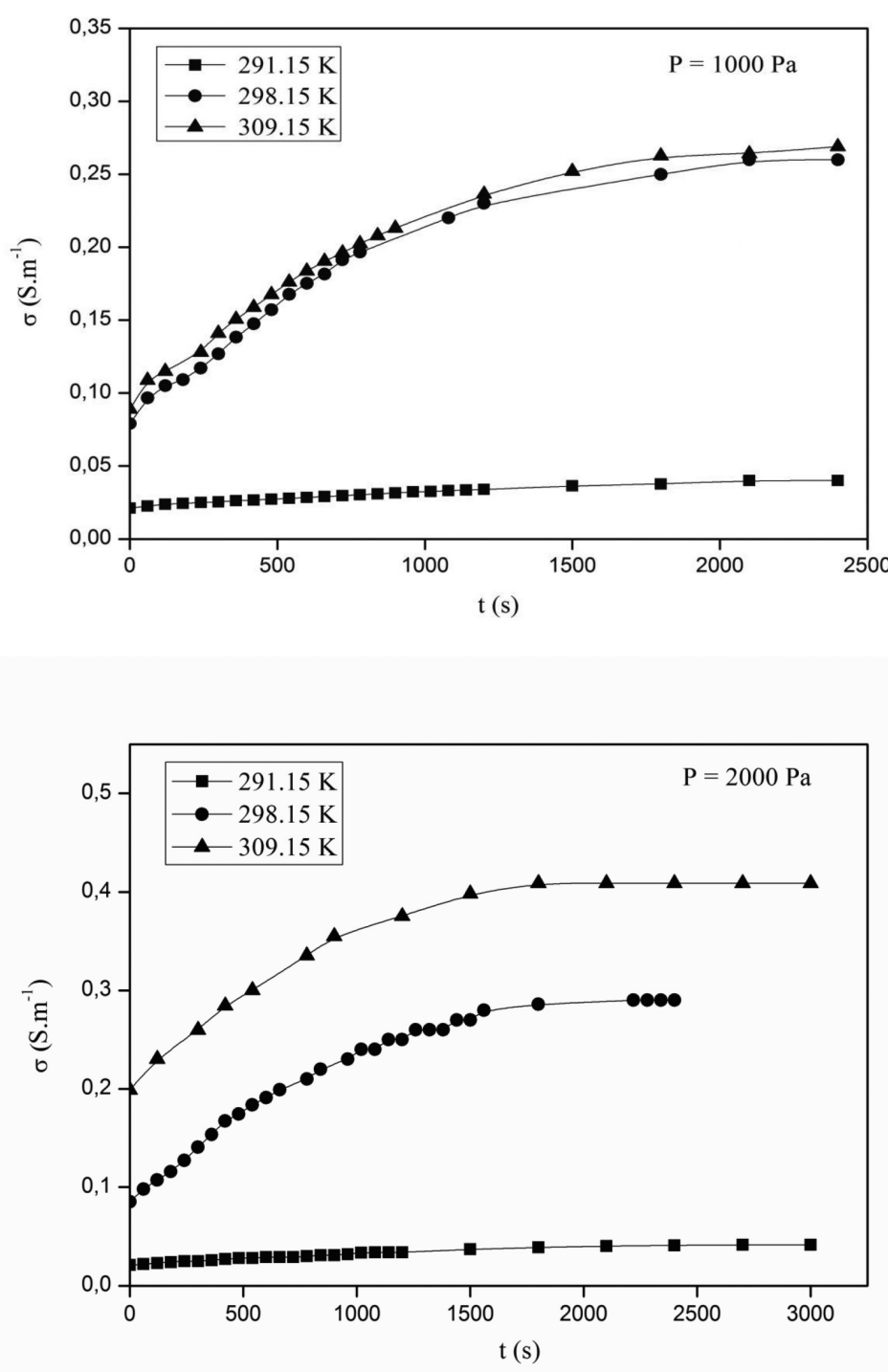

FIGURE 2. Conductivity versus time at different temperatures. Case of tablets from arbutus-berry powder obtained with a pressure of 1000 and $2000 \mathrm{~Pa}$; surrounding liquid: bidistilled water 
$309 \mathrm{~K}$ is 1.5 times higher than that at 298 , whereas for $1000 \mathrm{~Pa}$, the curve shape for both temperatures are almost identical. This behavior could be linked to the complex mechanisms resulting from contact between tablets and surrounding liquid medium. This complexity is due to the physicochemical phenomena that occur when two solid phases (tablet) and liquid (surrounding liquid) are contacted: Penetration of certain molecules of the liquid in the interstitial spaces of the tablet; solubilization of organic substances (electrolytes and non-electrolytes); transport of solubilized molecules in the surrounding liquid; increase of the concentration of charged particles in the liquid phase which leads to an increase of the EC; interaction effects between (+) and (-) electric charges which can involve the complexation phenomena (case of electrostatic attraction) and therefore a decrease in conductivity; and delay in the disintegration process of agglomerates of fruit powder.

As that generally takes place, the tablet surface disintegrates into granules that in turn disaggregate into fine particles, this process being moreover intensified by the effect of the high temperature of $309 \mathrm{~K}$. So, the heat effect can for example simultaneously accelerate the delitescence of the tablet surface and expulsion of the obstruent viscous liquid from capillaries and subsequently the ion transfer into liquid medium. These findings are supported by those communicated by Nilsson et al. (2003) who showed that the conductivity decreases with increasing tablet density.

TABLE 2. Parameters and statistical tests of the selected models related to dissolution of tablets obtained under pressures of 1000 and $2000 \mathrm{~Pa}$, in distilled water

\begin{tabular}{|c|c|c|c|c|c|}
\hline \multirow{2}{*}{$\begin{array}{l}\text { Pressure } \\
(\mathrm{Pa})\end{array}$} & \multirow[t]{2}{*}{$\mathrm{T}(\mathrm{K})$} & \multirow{2}{*}{$\begin{array}{c}\text { Parameters and } \\
\text { statistical test }\end{array}$} & \multicolumn{3}{|c|}{ Models } \\
\hline & & & Peleg & $\begin{array}{c}\text { Singh \& Kulshrestha } \\
\text { (1987) }\end{array}$ & $\begin{array}{l}\text { Singh et al. } \\
\text { (1981) }\end{array}$ \\
\hline \multirow[t]{18}{*}{1000} & \multirow[t]{6}{*}{291} & $\mathrm{R}^{2}$ & 0.893 & 0.987 & 0.966 \\
\hline & & $\mathrm{k}_{1}\left(\mathrm{~m} \cdot \mathrm{s} \cdot \mathrm{S}^{-1}\right)$ & $5.86 \times 10^{-2}$ & - & - \\
\hline & & $\mathrm{k}_{2}\left(\mathrm{~m} \cdot \mathrm{S}^{-1}\right)$ & $2.93 \times 10^{-2}$ & - & - \\
\hline & & $\mathrm{k}\left(\mathrm{s}^{-1}\right)$ & $5.00 \times 10^{-4 *}$ & $1.25 \times 10^{-3}$ & $1.07 \times 10^{-3}$ \\
\hline & & SEE & $2.18 \times 10^{-5}$ & $3.21 \times 10^{-5}$ & $3.21 \times 10^{-5}$ \\
\hline & & RMSE & $4.67 \times 10^{-3}$ & $5.66 \times 10^{-3}$ & $0.66 \times 10^{-3}$ \\
\hline & \multirow[t]{6}{*}{298} & $\mathrm{R}^{2}$ & 0.939 & 0.956 & 0.987 \\
\hline & & $\mathrm{k}_{1}\left(\mathrm{~m} \cdot \mathrm{s} \cdot \mathrm{S}^{-1}\right)$ & $44.37 \times 10^{-4}$ & - & - \\
\hline & & $\mathrm{k}_{2}\left(\mathrm{~m} \cdot \mathrm{S}^{-1}\right)$ & $0.34 \times 10^{-5}$ & - & - \\
\hline & & $\mathrm{k}\left(\mathrm{s}^{-1}\right)$ & $7.68 \times 10^{-4 *}$ & $1.59 \times 10^{-4}$ & $1.58 \times 10^{-3}$ \\
\hline & & SEE & $3.19 \times 10^{-3}$ & $3.34 \times 10^{-4}$ & $1.66 \times 10^{-2}$ \\
\hline & & RMSE & $5.65 \times 10^{-2}$ & $6.30 \times 10^{-3}$ & $1.29 \times 10^{-2}$ \\
\hline & \multirow[t]{6}{*}{309} & $\mathrm{R}^{2}$ & 0.960 & 0.952 & 0.9745 \\
\hline & & $\mathrm{k}_{1}\left(\mathrm{~m} \cdot \mathrm{s} \cdot \mathrm{S}^{-1}\right)$ & $4.18 \times 10^{-3}$ & - & - \\
\hline & & $\mathrm{k}_{2}\left(\mathrm{~m} \cdot \mathrm{S}^{-1}\right)$ & $0.36 \times 10^{-5}$ & - & - \\
\hline & & $\mathrm{k}\left(\mathrm{s}^{-1}\right)$ & $0.87 \times 10^{-3 *}$ & $2.02 \times 10^{-3}$ & $1.77 \times 10^{-3}$ \\
\hline & & SEE & $1.87 \times 10^{-3}$ & $2.70 \times 10^{-2}$ & $3.05 \times 10^{-2}$ \\
\hline & & RMSE & $4.32 \times 10^{-2}$ & $1.64 \times 10^{-1}$ & $1.75 \times 10^{-1}$ \\
\hline \multirow[t]{18}{*}{2000} & \multirow[t]{6}{*}{291} & $\mathrm{R}^{2}$ & 0.794 & 0.998 & 0.922 \\
\hline & & $\mathrm{k}_{1}\left(\mathrm{~m} \cdot \mathrm{s} \cdot \mathrm{S}^{-1}\right)$ & $54.50 \times 10^{-3}$ & - & - \\
\hline & & $\mathrm{k}_{2}\left(\mathrm{~m} \cdot \mathrm{S}^{-1}\right)$ & $2.97 \times 10^{-5}$ & - & - \\
\hline & & $\mathrm{k}^{2}\left(\mathrm{~s}^{-1}\right)$ & $0.55 \times 10^{-3 *}$ & $0.52 \times 10^{-3}$ & $1.38 \times 10^{-3}$ \\
\hline & & SEE & $4.81 \times 10^{-5}$ & $2.37 \times 10^{-2}$ & $8.26 \times 10^{-4}$ \\
\hline & & RMSE & $6.94 \times 10^{-2}$ & $1.54 \times 10^{-1}$ & $2.88 \times 10^{-2}$ \\
\hline & \multirow[t]{6}{*}{298} & $\mathrm{R}^{2}$ & 0.939 & 0.992 & 0.9261 \\
\hline & & $\mathrm{k}_{1}\left(\mathrm{~m} \cdot \mathrm{s} \cdot \mathrm{S}^{-1}\right)$ & $42.45 \times 10^{-4}$ & - & - \\
\hline & & $\mathrm{k}_{2}\left(\mathrm{~m} \cdot \mathrm{S}^{-1}\right)$ & $2.80 \times 10^{-6}$ & - & - \\
\hline & & $\mathrm{k}\left(\mathrm{s}^{-1}\right)$ & $0.65 \times 10^{-3 *}$ & $0.50 \times 10^{-3}$ & $1.82 \times 10^{-3}$ \\
\hline & & SEE & $5.88 \times 10^{-3}$ & $5.54 \times 10^{-1}$ & $3.05 \times 10^{-2}$ \\
\hline & & RMSE & $7.67 \times 10^{-2}$ & $7.44 \times 10^{-1}$ & $1.75 \times 10^{-1}$ \\
\hline & \multirow[t]{6}{*}{309} & $\mathrm{R}^{2}$ & 0.974 & 0.9945 & 0.954 \\
\hline & & $\mathrm{k}_{1}\left(\mathrm{~m} . \mathrm{s} . \mathrm{S}^{-1}\right)$ & $87.87 \times 10^{-6}$ & - & - \\
\hline & & $\mathrm{k}_{2}\left(\mathrm{~m} \cdot \mathrm{S}^{-1}\right)$ & $3.40 \times 10^{-6}$ & - & - \\
\hline & & $\mathrm{k}\left(\mathrm{s}^{-1}\right)$ & $0.10 \times 10^{-3 *}$ & $0.88 \times 10^{-3}$ & $1.87 \times 10^{-3}$ \\
\hline & & SEE & $1.00 \times 10^{-1}$ & $3.07 \times 10^{-1}$ & $2.72 \times 10^{-2}$ \\
\hline & & RMSE & $3.16 \times 10^{-1}$ & $7.85 \times 10^{-1}$ & $1.83 \times 10^{-1}$ \\
\hline
\end{tabular}

* calculated as $k_{2} / k_{1}$ 
TABLE 3. Activation energy related to dissolution of tablets

\begin{tabular}{ccccccc}
\hline \multirow{2}{*}{$\begin{array}{c}\text { Pressure } \\
(\mathrm{Pa})\end{array}$} & \multicolumn{2}{c}{ Peleg } & \multicolumn{2}{c}{ Singh \& kulshrestha (1987) } & \multicolumn{2}{c}{ Singh et al. (1981) } \\
\cline { 2 - 6 } & $\mathrm{R}^{2}$ & $\mathrm{E}_{\mathrm{a}}\left(\mathrm{kJ} \cdot \mathrm{mol}^{-1}\right)$ & $\mathrm{R}^{2}$ & $\mathrm{E}_{\mathrm{a}}\left(\mathrm{kJ} \cdot \mathrm{mol}^{-1}\right)$ & $\mathrm{R}^{2}$ & $\mathrm{E}_{\mathrm{a}}\left(\mathrm{kJ} \cdot \mathrm{mol}^{-1}\right)$ \\
\hline 1000 & 0.833 & 21.380 & 0.886 & 18.740 & 0.824 & 19.248 \\
2000 & 0.975 & 28.475 & 0.800 & 23.104 & 0.726 & 11.481 \\
\hline
\end{tabular}

The average values of the parameters related to various mathematical models, as well as corresponding statistical data applied are recapitulated in Table 2. It must be noticed that the appropriate model is a priori unknown.

It must be precised that the $\mathrm{k}$ Peleg constant is calculated as $\mathrm{k}_{2} / \mathrm{k}_{1}$ ratio. As can be seen, whatever the temperature and compression force values, $\mathrm{k}_{1}$ is higher than $\mathrm{k}_{2}$, what is in conformity with the literature data devoted to the matter transfer (including water and other molecules) and implicating numerous food matrixes at different temperatures (Cox et al. 2012; Rhim et al. 2011; Yildirim et al.2010). In addition, according to statistical data, the adequacy of models seems to be influenced by both parameters (temperature and compression force). However, the model of Singh and Kulshrestha appears to be more appropriate to describe the kinetics of dissolution of tablets, especially for compression force of $2000 \mathrm{~Pa}$ $\left(\mathrm{R}^{2}=0.99\right)$. On the contrary, concerning rehydration and dissolution of freeze-dried rice pulps, Rhim et al. (2011) have found that the model of Peleg fit more adequately experimental data, compared with that of Singh and Kulshrestha.

To the best of our knowledge, there are no data about the temperature dependence of ionic transfer in food matrixes-surrounding liquid systems, the values found regarding the activation energy (Table 3) are in concordance with that $\left(20 \mathrm{~kJ} \mathrm{~mole}^{-1}\right)$ related to the diffusion of ions through liquids (Gronow 1987).

\section{CONCLUSION}

The results showed that Arbutus berry (Arbutus unedo L.) fruits can be easily processed into powder and then into tablets by direct compression. The obtained tablets are of various applications, namely their consumption as such and their use as a carrier for dried extract from other plant species.

In addition, the dissolution kinetics of the tablets, investigated throughout EC of the surrounding medium is before all correctly described by Sing and Kulshrestha model $\left(\mathrm{R}^{2}>0.99\right.$ in certain cases), whereas the activation energy ranged between 18.7 and $28.5 \mathrm{~kJ} \mathrm{~mol}^{-1}$.

\section{REFERENCES}

Adiba, B.D., Benamara, S., Saidi, N. \& Meksoud, A. 2011. Preliminary characterization of food tablets from date (Phoenix dactylifera L.) and spirulina (Spirulina sp.) powders. Powder Technology 208(3): 725-730.
Alarcão-E-Silva, M.L.C.M.M.,Leitão, A.E.B.,Azinheira, H.G. \& Leitão, M.C.A. 2001. The arbutus berry: Studies on its color and chemical characteristics at two mature stages. Journal of Food Composition and Analysis 14: 27-35.

Allane, T. \& Benamara, S. 2010. Antioxidant activities of some common and wild fruits from Algeria. Phytothérapie 8(3): 171-175.

Almukainzi, M., Salehi, M., Bou-Chacra, N.A. \& Löbenberg, R. 2010. Investigation of the performance of the disintegration test for dietary supplements. The AAPS Journal 12(4): 602607.

Amin, M.C.I.M.,Abadi, A.G.,Ahmad, N., Katas, H. \& Jamal, J.A. 2012. Bacterial cellulose film coating as drug delivery system: Physicochemical, thermal and drug release properties. Sains Malaysiana 41(5): 561-568.

Arama, E., Michaud, P., Rouffiac, R. \& Rodriguez, F. 1989. Biodisponibilité de comprimés à libération prolongée de théophylline et de paracétamol formulés avec la pulpe de fruit du baobab. Pharmaceutica Acta Helvetiae 64: 116-120.

Ayaz, F.A., Kucukislamoglu, M. \& Reunanen, M. 2000. Sugar, non-volatile and phenolic acids composition of strawberry tree (Arbutus unedo L. var. ellipsoidea) fruits. Journal of Food Composition and Analysis 13: 171-177.

Benamara, S., Aksil, T., Boukhiar, A., Megdoud, Dj., Iguergaziz, N., Babouri, S., Galouz, M.S., Nakib, W. \& Rahal, S. 2012. Tabletting: Alternative way of valorization of agro-resources. Proceeding of the Third International Scientific Symposium Agrosym, Jahorina (Bosnia).

Bhagavan, H.N. \& Wolkoff, B.I. 1993. Correlation between the disintegration time and the bioavailability of vitamin $\mathrm{C}$ tablets. Pharmaceutical Research 10(2): 239-242.

Brielles, N., Chantraine, F., Viana, M., Chulia, D., Branlarrd, P., Rubinstenn, G., Lequeux, F. \& Mondain-Monval, O. 2008. Dissolution of a surfactant containing active porous material. Journal of Colloid Interface Science 328(2): 344-352.

Boussetta, N., Lanoisellé, J.L., Bedel-Cloutour, C. \& Vorobiev, E. 2009. Extraction of soluble matter from grape pomace by high voltage electrical discharges for polyphenol recovery: Effect of sulphur dioxide and thermal treatments. Journal of Food Engineering 95(1): 192-198.

Chantraine, F., Viana, M., Brielles, N., Mondain-Monval, O., Pouget, C., Branlard, P., Rubinstenn, G. \& Chulia, D. 2006. Parametric study of surfactant effect on mechanical and dissolution properties of detergent tablets. Journal of Surfactants and Detergents 9(3): 267-277.

Costa, P. \& Sousa Lobo, J.M. 2001. Modeling and comparison of dissolution profiles. European Journal of Pharmaceutical Sciences 13(2): 123-133.

Cox, S., Gupta, Sh. \& Abu-Ghannam, N. 2012. Effect of different rehydration temperatures on the moisture, content of phenolic compounds, antioxidant capacity and textural properties of edible Irish brown seaweed. LWT - Food Science and Technology 47(2): 300-307. 
Devla, M.N., Acharya, S.R., Acharya, N.S. \& Kumar, V. 2011. Dietary supplements: A legal status in India \& in foreign countries. International Journal of Pharmacy and Pharmaceutical Sciences 3: 7-12.

Frenning, G., Ek, R. \& Strømme, M. 2002. A new method for characterizing the release of drugs from tablets in low liquid surroundings. Journal of Pharmaceutical Sciences 91: 776-784.

Gauza, M. \& Kubisz, L. 2010. Electrical conductivity of fish skin collagen in the temperature range 290-380 K. Acta Physica. Polonica 118(1): 54-57.

Göczo, H., Szabo-Revesz, P., Farkas, B. \& Hasznos-Nezdei, M. 2000. Development of spherical crystals of acetylsalicylic acid for direct tablet-making. Chemical \& Pharmaceutical Bulletin 48(12): 1877-1881.

Gronow, J.R. 1987. The dissolution of asbestos fibers in water. Clay Minerals 22: 21-35.

Hill, M.C. 2006. The practical use of simplicity in developing ground water models. Ground Water 44(6): 775-781.

Jayjock, E., Schmitt, R., Chien, Ch. \& Tirol, G. 2005. Annual Meeting and Exposition of the American Association of Pharmaceutical Scientists Nashville, Tennessee, November 6-10.

Kampuse, S. \& Volkova, I. 2009. Effects of packaging and preparation method on the quality of freeze-dried blackcurrant products. Cheminé Technologija 3(52): 37-42.

Ku, M.Sh., Lu, Q., Li, W. \& Chen, Y. 2011. Performance qualification of a new hypromellose capsule. Part II. Disintegration and dissolution comparison between two types of hypromellose capsules. International Journal of Pharmaceutics 386(1): 30-41.

Madrigal-Carballo, S., Lim, S., Rodriguez, G., Vila, A.O., Krueger, Ch.G., Gunasekaran, S. \& Reed, J.D. 2010. Biopolymer coating of soybean lecithin liposomes via layerby-layer self-assembly as novel delivery system for ellagic acid. Journal of Functional Foods 2(2): 99-106.

Mikac, U., Demsar, A., Demsar, F. \& Sersa, I. 2007. A study of tablet dissolution by magnetic resonance electric current density imaging. Journal of Magnetic Resonance 185: 103109.

Murrieta-Pazos, I., Gaiani, C., Galet, L., Calvet, R., Cuq, B. \& Scher, J. 2012. Food powders: Surface and form characterization revisited. Journal of Food Engineering 112(1-2): 1-21.

Nilsson, M., Alderborn, G. \& Strømme, M. 2003. Water-induced charge transport in tablets of microcrystalline cellulose of varying density: Dielectric spectroscopy and transient current measurements. Chemical Physics 295: 159-165.

Olayemi, O.J., Oyi, A.R. \& Allagh, T.S. 2011. Comparative evaluation of maize, rice and wheat starch powders as pharmaceutical excipients. Nigerian Journal of Pharmaceutical Sciences 7(1): 131-138.

Orak, H.H., Aktas, T., Yagar, H., Isbilir, S.S., Ekinci, N. \& Sahin, F.H. 2011. Antioxidant activity, some nutritional and color properties of vacuum dried strawberry tree (Arbutus unedo L.) fruit. Acta Scientiarum Polonorum, Technologia Alimentaria 10(3): 327-338.

Özcan, M.M. \& Hacıseferoğulları, H. 2007. The Strawberry (Arbutus unedo L.) fruits: Chemical composition, physical properties and mineral contents. Food Engineering 78: 1022-1028.

Pallauf, K., Rivas-Gonzalo, J.C., del Castillo, M.D., Cano, M.P. \& Pascual-Teresa, S. 2008. Characterization of the antioxidant composition of strawberry tree (Arbutus unedo L.) fruits. Journal of Food Composition and Analysis 21(4): 273-281.

Panda, D., Choudhury, N.S.K., Yedukondalu, M., Si, S. \& Gupta, R. 2008. Evaluation of gum of Moringa oleifera as a binder and release retardant in tablet formulation. Indian Journal of Pharmacology 70(5): 614-618.

Patel, R.P. \& Bhavsar, M. 2009. Directly compressible materials via co-processing. International Journal of Pharm. Tech. Research 1(3): 745-753.

Patil, M., Kale, V. \& Tapre, C. 2012. Design and validation of 'Flomex': An instrument for powder flow measurement. International Journal Food Agriculture Veterinary Science 2(1): 40-46.

Pawlowska, A.M., De Leo, M. \& Braca, A. 2006. Phenolics of Arbutus unedo L. (Ericaceae) fruits: Identification of anthocyanins and gallic acid derivatives. Journal of Agricultural and Food Chemistry 54(26): 10234-10238.

Peleg, M. 1988. An empirical model for description of moisture sorption curves. Journal of Food Science 53: 1216-1219.

Prakash, S.S., Patra, Ch.N., Santanu, Ch., Kumar, P.H., Patro, V.J. \& Devi, M.V. 2011. Studies on flowability, compressibility and in vitro release of Terminalia Chebula fruit powder tablets. Iranian Journal of Pharmaceutical Research 10(3): 393-401.

Rahman, M.Sh. 2007. Allicin and other functional active components in garlic: Health benefits and bioavailability. International Journal of Food Properties 10(2): 245-268.

Rhim, J.W., Koh, S. \& Kim, J.M. 2011. Effect of freezing temperature on rehydration and water vapor adsorption characteristics of freeze-dried rice porridge. Journal of Food Engineering 104(4): 484-491.

Ruiz-Rodríguez, B.M., Morales, P., Fernández-Ruiz, V., SánchezMata, M.C., Cámara, M., Díez-Marqués, C., Pardo-deSantayana, M., Molina, M. \& Tardío, J. 2011. Valorization of wild strawberry-tree fruits (Arbutus unedo L.) through nutritional assessment and natural production data. Food Research International 44: 1244-1253.

Salbu, L. 2011. Compressibility and compactibility of pectin powders: A study of their potential as direct compression excipients in tablets. Faculty of Health Sciences, University of Troms $\varnothing$, Norway. PhD Thesis (unpublished).

Singh, B.P.N. \& Kulshrestha, S.P. 1987. Kinetics of water sorption by soybean and pigeonpea grains. Journal of Food Science 52(6): 1534-1541.

Singh, B.P.N., Narain, M. \& Singh, H. 1981. Kinetics of water vapor sorption by wheat flour from saturated atmosphere. Journal of Food Science and Technology 18(5): 201-206.

Tawaha, K., Alali, F.Q., Gharaibeh, M., Mohammad, M. \& El-Elimat, T. 2007. Antioxidant activity and total phenolic content of selected Jordanian plant species. Food Chemistry 104(4): 1372-1378.

Vudathala, G.K. \& Rogers, J.A. 1992. Dissolution of fludrocortisone from phospholipid coprecipitates. Journal of Pharmaceutical Sciences 82: 282-286.

Yildirim,A.,Öner, M.D. \& Bayram, M. 2010. Modeling of water absorption of ultrasound applied Chickpeas (Cicer arietinum L.) using Peleg's equation. Journal of Agricultural Sciences 16(4): 278-286.

Young, P.M., Nguyen, K., Jones, A.S. \& Daniela Traini, D. 2008 Microstructural analysis of porous composite materials: Dynamic imaging of drug dissolution and diffusion through porous matrices. The AAPS Journal 10(4): 560-564. 
Yu, L.X. 2008. Use and Limitations of In Vitro Dissolution Testing: Topic Introduction and Overview. U.S. Food and Drug Administration, 2012 (www.fda.gov).
*Corresponding author; email: sbenamara2001@yahoo.fr

Received: 23 April 2013

Accepted: 5 August 2014

Research Laboratory in Food Technology (LRTA)

Faculty of Engineering Science

University M'hamed Bougara of Boumerdès

35000 Boumerdès

Algeria 